\title{
Characterization of Glucosyltransferase Expressed from a Streptococcus sobrinus Gene Cloned in Escherichia coli
}

\author{
By R. R. B. RUSSELL, ${ }^{1 *}$ M. L. GILPIN, ${ }^{1}$ H. MUKASA ${ }^{2}$ AND G. DOUGAN ${ }^{3}$ \\ ${ }^{1}$ Dental Research Unit, Royal College of Surgeons of England, Downe, Kent BR6 7JJ, UK \\ ${ }^{2}$ Department of Chemistry, National Defense Medical College, Tokorozawa, Saitama 359, Japan \\ ${ }^{3}$ Wellcome Research Laboratories, Beckenham, Kent BR3 3BS, UK
}

(Received 24 July 1986; revised 13 October 1986)

\begin{abstract}
The gene encoding a glucosyltransferase which synthesized water-insoluble glucan, gtfI, previously cloned from Streptococcus sobrinus strain MFe28 (mutans serotype $h$ ) into a bacteriophage $\lambda$ vector, was subcloned into the plasmid pBR322. The recombinant plasmid was stable in Escherichia coli and $g t f I$ was efficiently expressed. The GTF-I expressed in E. coli was compared to the corresponding enzymes in $S$. sobrinus strains MFe28 (serotype $h$ ), B13 (serotype $d$ ) and 6715 (serotype $g$ ) and shown to resemble them closely in molecular mass and isoelectric point. The insoluble glucan produced by GTF-I from recombinant $E$. coli consisted of 1,3- $\alpha$-Dglycosyl residues $(\sim 90 \%)$. An internal fragment of the $g t f I$ gene was used as a probe in hybridization experiments to demonstrate the presence of homologous sequences in chromosomal DNA of other streptococci of the mutans group.
\end{abstract}

\section{INTRODUCTION}

The glucosyltransferases (GTFs) of the mutans group of oral streptococci are extracellular enzymes responsible for the synthesis of complex mixtures of water-soluble and insoluble glucans. These glucans are believed to be important in the formation and metabolism of dental plaque (Hamada \& Slade, 1980). It was first shown by Guggenheim \& Newbrun (1969) that a single strain could produce a number of electrophoretically distinct GTFs. Ciardi et al. (1976, 1977) showed that some of these enzymes synthesized soluble, and others insoluble, polymers but progress towards understanding the reason for the multiplicity of enzymes has been considerably hampered by technical problems, including the fact that GFTs exist in highmolecular-mass aggregates and have a strong tendency to bind to separation matrices commonly used in column chromatography (Germaine et al., 1977; Russell, 1979; Figures \& Edwards, 1981; Ono et al., 1984). The latter fact has, however, proved useful in purification procedures involving affinity chromatography (McCabe \& Smith, 1977; Russell, 1979; McCabe, 1985). At least some of the heterogeneity of GTFs is a consequence of proteolytic degradation (Asem et al., 1986; Mukasa, 1986; Russell et al., 1986), but many questions remain concerning the number of distinct GTFs and their individual functions.

Most progress has been made with strains that originally constituted Streptococcus mutans serotypes $d$ and $g$, which are now classified as Streptococcus sobrinus (Coykendall, 1983; Coykendall \& Gustafson, 1986). The purification from strains of these serotypes of GTFs capable of synthesizing soluble glucans (GTF-S) or insoluble glucans (GTF-I) has been described by a number of workers (Ciardi et al., 1977; Germaine et al., 1977; Hare et al., 1978; Figures \& Edwards, 1981 ; Fukushima et al., 1981 ; Fukui et al., 1982; Koga et al., 1983; Robyt \& Martin, 1983; Furuta et al., 1985; McCabe, 1985; Namiki et al., 1985; Mukasa, 1986). The glucan synthesized by GTF-S (dextran) consists mainly of 1,6- $\alpha$-linked glucose units while that

Abbreviations: GTF, glucosyltransferase; PAS, periodic acid-Schiff. 
synthesized by GTF-I (mutan) is rich in 1,3- $\alpha$-linkages. Recently, the existence of another GTF, which makes a soluble glucan but is distinguished by the fact that it requires no dextran primer in order to function, has been reported (Tsumori et al., 1983; McCabe, 1985). We refer to this as GTF-S2 and to the primer-dependent enzyme as GTF-S1 (Mukasa, 1986). These three different GTFs can be distinguished by isoelectric focusing (Tsumori et al., 1983) and are immunologically distinct (Shimamura et al., 1983; Mukasa, 1986).

The GTFs of strains of $S$. sobrinus serotype $h$, which is closely related to serotypes $d$ and $g$, have not been investigated in detail, although they were reported to have similar molecular masses and isoelectric points to serotype $d$ and $g$ enzymes and to cross-react antigenically with the latter (Beighton et al., 1981; Gilpin et al., 1985). Serotype $h$ strains were, however, remarkable in that virtually all the glucan they produced was insoluble and bound to the bacteria in sucrose-containing media (Beighton et al., 1981).

In order to investigate the GTFs of $S$. sobrinus serotype $h$ strains and aid in the characterization of the different forms of GTFs, we have introduced a genetic approach and have described the cloning of genes for a GTF-S and a GTF-I in a bacteriophage $\lambda$ vector (Gilpin et al., 1985). This paper describes further studies on the cloned gene for GTF-I and compares the enzyme specified by it with GTF of the $S$. sobrinus strain from which it was derived.

\section{METHODS}

Strains and culture conditions. The strains used in this study were as follows: Streptococcus cricetus strain AHT (mutans serotype a); Streptococcus rattus strain FAI (serotype $b$ ); S. mutans strains Ingbritt (serotype $c$ ), C40 (serotype $e$ ) and 151 (serotype $f$ ); and $S$. sobrinus strains K1 (serotype $g$ ), 6715 (serotype $g$ ) and MFe28 (serotype $h$ ). All were from existing laboratory stocks apart from $S$. mutans strain $\mathrm{C} 40$, which was recently isolated from plaque of a child in Hampshire (D. Beighton, personal communication). For biochemical studies, mutans bacteria were grown in either the chemically defined medium of Terleckyj et al. (1975) or the same medium with $0.5 \%(\mathrm{w} / \mathrm{v})$ casein hydrolysate (Oxoid) substituted for the mixture of individual amino acids. Cultures of $E$. coli strains DH1 (Davis et al., 1980) or DS410 (Dougan \& Kehoe, 1984) carrying plasmids were grown in either LB broth (Davis et al., 1980) or Brain Heart Infusion broth (Oxoid) containing the appropriate antibiotics: tetracycline $\left(15 \mu \mathrm{g} \mathrm{m}^{-1}\right)$, ampicillin $\left(100 \mu \mathrm{g} \mathrm{ml}^{-1}\right)$ or both antibiotics.

Isolation of streptococcal DNA. The bacteria were grown in Todd-Hewitt broth (Oxoid) supplemented with DLthreonine (20 mM) and DNA was prepared as described by Monsen et al. (1983). The mutanolysin Ml enzyme (Yokogawa et al., 1975) used to lyse the bacteria was a gift from M. Yokogawa, Dainippon Pharmaceutical Company Japan.

Isolation of plasmid DNA. Plasmid DNA was extracted using the Triton X-100 procedure (Davis et al., 1980) and purified by ultracentrifugation in caesium chloride gradients containing ethidium bromide (Maniatis et al., 1982).

Isolation of bacteriophage $D N A$. Bulk phage lysates were prepared by propagating bacteriophage on $E$. coli strain C600 (Davis et al., 1980) grown in liquid M9 minimal salts medium containing the following supplements: casein hydrolysate $\left(10 \mathrm{~g} \mathrm{l}^{-1}\right)$, glucose $\left(4 \mathrm{~g}^{-1}\right)$, maltose $\left(4 \mathrm{~g}^{-1}\right)$ and thiamin $\left(10 \mu \mathrm{gl}^{-1}\right)$. DNA was isolated from the phage as described by Maniatis et al. (1982).

DNA manipulations. Restriction endonuclease digestions and ligation reactions were performed according to the supplier's guidelines (Boehringer). Transformation of $E$. coli recipients with plasmid DNA was done according to the method of Cohen et al. (1973).

Subcloning gene gtfI on to plasmid pBR322. The construction of recombinant bacteriophage $\lambda \mathrm{MFeA}$ carrying gene $g t f I$ from $S$. sobrinus strain MFe28 has been described (Gilpin et al., 1985). DNA purified from bacteriophage $\lambda \mathrm{MFeA}$ was digested to completion with HindIII and ligated with pBR322 DNA cleaved with HindIII, using T4 DNA ligase. The ligation mixture was used to transform E. coli strain DH1. Transformants were selected on LB agar plates containing ampicillin $\left(100 \mu \mathrm{g} \mathrm{ml}^{-1}\right)$. Transformants containing inserts were detected as tetracycline-sensitive $\left(\mathrm{Tc}^{\mathrm{s}}\right)$ by replica-plating on tetracycline-containing medium. Each $\mathrm{Tc}^{\mathrm{s}}$ transformant was streaked on sucrose indicator medium containing agar $\left(10 \mathrm{~g} \mathrm{l}^{-1}\right)$, sucrose $\left(10 \mathrm{~g} \mathrm{l}^{-1}\right)$, tryptone $\left(5 \mathrm{~g} \mathrm{l}^{-1}\right)$, sodium chloride $\left(5 \mathrm{~g} \mathrm{l}^{-1}\right)$ and bromothymol blue (200 $\left.\mathrm{mg} \mathrm{1}^{-1}\right)$, adjusted to $\mathrm{pH} 7 \cdot 0$. Transformants capable of utilizing sucrose were detected by the appearance of yellow-orange colonies.

Minicell analysis of the polypeptides encoded by $p M L G 10$. Plasmids were introduced into the minicell-producing E. coli strain DS410 by transformation. Use of the minicell system and the methods employed were as described by Dougan \& Kehoe (1984).

Southern-blot hybridization. A 3.3 kbp HpaI fragment from within the cloned gtfI sequence was isolated from pMLGI DNA using the procedure given by McDonnell et al. (1977). The Hpal fragment was radiolabelled with 
[ $\left.\alpha{ }^{-32} \mathrm{P}\right] \mathrm{dATP}$ using the nick translation method described by Feinberg $\&$ Vogelstein (1983) and used to probe for homologous sequences in $\mathrm{HpaI}$ chromosomal DNA fragments from representative strains of each of the eight mutans serotypes, using the method of Southern (1975) as described by Maniatis et al. (1982).

Electrophoresis and isoelectric focusing. The conditions for sodium dodecyl sulphate polyacrylamide gel electrophoresis (SDS-PAGE), detection of GTF activity on gels and detection of antigens by Western blotting were all as used previously (Russell, 1979; Russell et al., 1985). Molecular mass standards (carbonic anhydrase, ovalbumin, bovine serum albumin, phosphorylase $b, \beta$-galactosidase and myosin) were from Sigma.

The procedure for isoelectric focusing of GTFs in the range $\mathrm{pH}$ 3-10 on thin layers of polyacrylamide and subsequent detection of GTF activity was as described by Tsumori et al. (1983). Calibration was done with the Broad pI kit supplied by Pharmacia. the pI of GTF-I purified from E. coli strain MAF10 was also determined using ultrathin layer polyacrylamide gels (Servalyt Precotes 3-10, Serva Feinbiochemical), using the manufacturer's instructions for electrophoresis and staining and a kit of standard proteins (pH 2.4-5.65; BDH). After focusing, standard marker proteins were stained with Coomassie brilliant blue. Glucosyltransferase activity was detected by overnight incubation of the gel at $37^{\circ} \mathrm{C}$ in phosphate buffer containing sucrose (Tsumori et al., 1983). Insoluble glucan was easily seen by dark-ground illumination, while soluble glucans were detected by staining with periodic acid-Schiff (PAS) reagent.

DNA fragments were analysed in 0.7 or $0.8 \%(\mathrm{w} / \mathrm{v})$ agarose gels, stained with ethidium bromide $\left(0.5 \mu \mathrm{g} \mathrm{ml} \mathrm{m}^{-1}\right)$ for $30 \mathrm{~min}$ and photographed under UV light through a Kodak Wratten 23A orange filter (Maniatis et al., 1982).

Purification of GTF-I. GTF-I was purified from lysates of $E$. coli strain $\mathrm{C} 600$ infected with recombinant bacteriophage $\lambda \mathrm{MFeA}$ and from cells of $E$. coli strain MAF10 (which carries plasmid pMLG10) by subjecting the bacteria to ultrasonic disruption and using a single-step affinity chromatography procedure : the bacterial lysate or extract was passed through a column containing Sepharose CL-6B (Pharmacia) and mutan. After washing with buffer, bound GTF-I was eluted with $6 \mathrm{M}$-guanidine. $\mathrm{HCl}$ (Russell et al., 1985).

Preparation of antisera. Antiserum to GTF-I prepared as described above was raised in a New Zealand White rabbit by a schedule of three intramuscular injections, three weeks apart, each of $100 \mu \mathrm{g}$ GTF-I combined with aluminium hydroxide (Alu Gel S, Serva) as adjuvant. The rabbit was bled one week after the final injection. Antisera to GTF-S1, GTF-S2 and GTF-I, purified from $S$. sobrinus strain 6715 as described elsewhere (Mukasa, 1986), were raised as described by Mukasa \& Slade (1973).

Characterization of glucans. For analysis by gas-liquid chromatography (GLC), the insoluble polymer formed by incubation of a crude extract of $E$. coli strain MAF10 (harbouring plasmid pMLG10) with sucrose was washed twice with water, subjected to complete methylation and hydrolysed to the partially methylated glucose derivatives. The derivatives were further reduced, acetylated, and the resultant partially methylated glucitol acetates analysed by GLC (Shimamura et $a l ., 1982$ ). The composition of the glucan was also analysed by ${ }^{13} \mathrm{C}$ nuclear magnetic resonance (NMR) spectrometry: glucan was washed with distilled water, dried and assayed at a concentration of $100 \mathrm{mg} \mathrm{ml}^{-1}$ in $\mathrm{D}_{2} \mathrm{O}$ containing $0.5 \mathrm{M}-\mathrm{NaOD}$. Sample temperature was $21^{\circ} \mathrm{C}$. Naturalabundance ${ }^{13} \mathrm{C}$ NMR spectra were recorded at $67.8 \mathrm{MHz}$ on a Jeol JNM-GX270 FT NMR spectrometer with spinning sample tubes of $5 \mathrm{~mm}$ outer diameter. The sample was pulsed with $45^{\circ}$ radio-frequency pulses $(3.6 \mu \mathrm{s}$ pulse width). A spectral width of $8000 \mathrm{~Hz}$ was used, and spectra accumulated at 16384 data points. Chemicals shifts were measured digitally and are reported in parts per million downfield from internal methyl carbon of 3(trimethylsilyl)propanesulphonic acid sodium salt. Assignment of peaks was based on the report by Colson $e t$ al. (1974).

\section{RESULTS}

\section{Size of insert of $S$. sobrinus DNA in recombinant bacteriophage $\lambda M F e A$}

Originally gene $g t f I$ was cloned into the BamHI sites of bacteriophage vector $\lambda \mathrm{L} 47.1$ on a Sau3A fragment of DNA from $S$. sobrinus strain MFe28. The recombinant bacteriophage was designated $\lambda \mathrm{MFeA}$ (Gilpin et al., 1985).

DNA purified from bacteriophages $\lambda$ MFeA and $\lambda$ L47.1 was digested separately with $E c o R I$, $H$ HindII and BamHI, and analysed by agarose gel electrophoresis. It was found that only one of the two Bam HI sites of bacteriophage $\lambda \mathrm{L} 47.1$ had been regenerated in the recombinant $\lambda \mathrm{MFeA}$. Digestion of $\lambda \mathrm{MFeA}$ DNA with HindIII gave six fragments of sizes $23,8 \cdot 2,5 \cdot 0,2 \cdot 6,2 \cdot 3$ and $0.5 \mathrm{kbp}$ (total $41.6 \mathrm{kbp}$ ). Digestion of $\lambda \mathrm{MFeA}$ DNA with EcoRI gave four fragments of sizes $21 \cdot 7,7.6,7.2$ and $5 \cdot 1 \mathrm{kbp}$ (total $41.6 \mathrm{kbp}$ ). Given that the size of the bacteriophage $\lambda \mathrm{L} 47.1$ genome with the BamHI stuffer fragment removed is $34 \mathrm{kbp}$ (Loenen \& Brammar, 1980), the size of insert of $S$. sobrinus strain MFe28 DNA in the recombinant bacteriophage $\lambda \mathrm{MFeA}$ was calculated to be $7.6 \mathrm{kbp}$. 

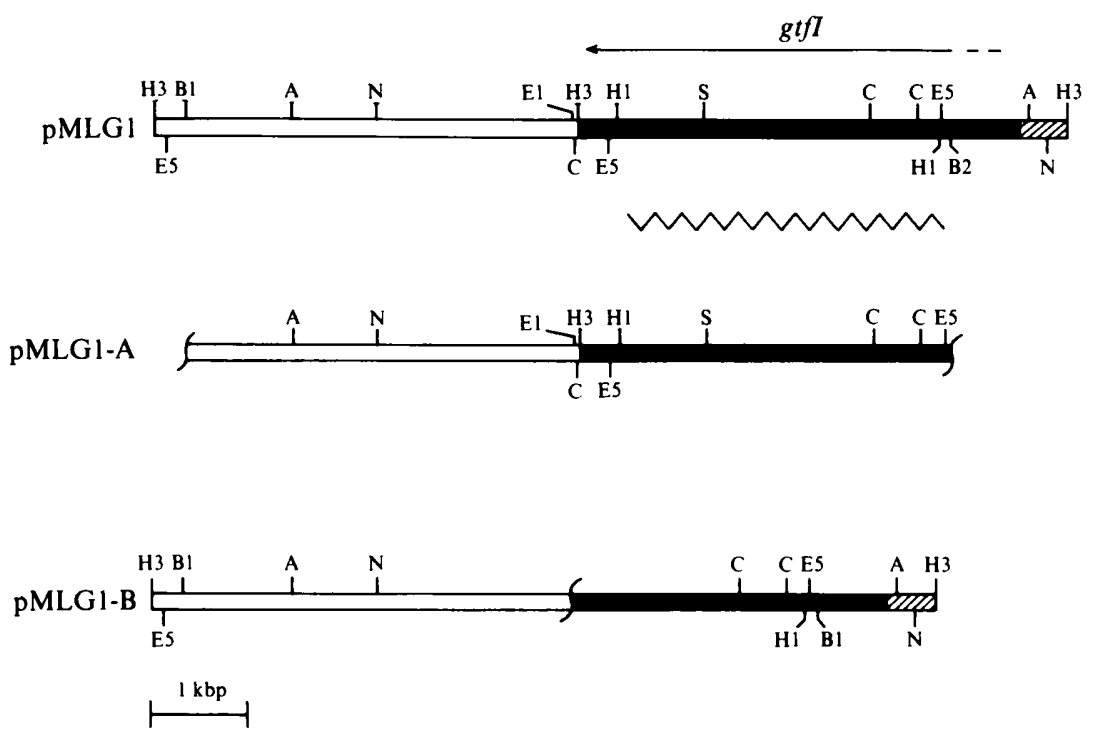

Fig. 1. Restriction map of recombinant plasmid pMLG1, which carries gene gtfI on a $5 \mathrm{kbp}$ HindIII fragment subcloned from recombinant bacteriophage $\lambda \mathrm{MFeA}$ into the HindIII site of vector plasmid pBR322. The double open lines represent plasmid pBR322 sequences, the solid bars represent $S$. sobrinus strain MFe28 DNA, and the hatched area represents bacteriophage $\lambda$ L47.1 DNA. Deletions introduced at either end of the insert produced plasmids pMLG1-A and pMLG1-B. pMLG1-A lacks a $1.55 \mathrm{kbp} \mathrm{Bg} / \mathrm{II}-$ BamHI fragment found in pMLG1, whereas pMLG1-B lacks a $1.33 \mathrm{kbp}$ EcoRI-SacI fragment. The arrow indicates the direction of transcription of gene $\mathrm{gtfI}$ (deduced from deletion analysis). The zig-zag line indicates the $3.3 \mathrm{kbp} \mathrm{HpaI}$ fragment used as probe in Southern hybridization experiments. Restriction endonucleases: A, Aval; B1, BamHI; B2, BglII; C, ClaI; E1, EcoRI; E5, EcoRV; H1, HpaI; H3, HindIII; N, NdeI; S, SacI.

\section{Sub-cloning gene gtfI on to plasmid pBR322}

DNA from recombinant bacteriophage $\lambda \mathrm{MFeA}$ was completely digested with HindIII and ligated with HindIII-cleaved pBR322 DNA. The ligation mixture was used to transform E. coli strain DH1 to ampicillin resistance $\left(\mathrm{Amp}^{r}\right)$. Of $440 \mathrm{Amp}^{r}$ transformants tested, $21(4.8 \%)$ were $\mathrm{Tc}^{\mathrm{s}}$, of which 11 gave a positive sucrose-utilization phenotype when streaked on sucroseindicator agar medium. Confirmation that gene gtfI had been sub-cloned came from a Western blot experiment using antiserum raised to GTF-I isolated from a bacteriophage $\lambda \mathrm{MFeA}$ lysate, and from the detection of bands of GTF activity in SDS-PAGE gels (not shown).

Plasmids in two of the Amp ${ }^{r}$ transformants have been characterized further. Plasmid pMLG1 has a $5 \mathrm{kbp}$ HindIII insert in pBR322, whereas pMLG10 has a $10 \mathrm{kbp}$ insert made up of two copies of the same $5 \mathrm{kbp}$ insert as in pMLG1 linked in tandem. A restriction endonuclease site map of pMLG 1 is shown in Fig. 1 . Approximately $0.5 \mathrm{kbp}$ at the right end of the insert is derived from the $\lambda$ phage vector (M. L. Gilpin, unpublished data). Thus the insert of $S$. sobrinus strain MFe28 DNA in pMLG1 is $4.5 \mathrm{kbp}$. Given that the molecular mass of GTF-I is about $160 \mathrm{kDa}$ (see below), and that $1 \mathrm{kbp}$ of DNA can code for a protein of molecular mass $37 \mathrm{kDa}$, it was estimated that gene $g t f I$ would occupy about $4.3 \mathrm{kbp}$ of DNA. The insert of $S$. sobrinus strain MFe28 DNA in pMLG1 therefore consists almost entirely of gene gtfl.

Deletions extending into either end of the insert in pMLGl were created by cleaving the DNA simultaneously with BglII and BamHI, or EcoRI and SacI (followed by 'polishing' the fragment ends with DNA polymerase I to create blunt ends), religating and transforming the deletion plasmids into E. coli strain DH1. Transformants bearing plasmids with the generated deletions were detected by their inability to produce acid on sucrose-indicator agar medium. Neither deletion plasmid pMLG1A, which lacks a $1.55 \mathrm{kbp} B g l \mathrm{II}-$ Bam HI fragment found in pMLG1, nor deletion plasmid pMLG1 B, lacking a $1.33 \mathrm{kbp} E c o \mathrm{RI}-S a c \mathrm{I}$ fragment, produced an 


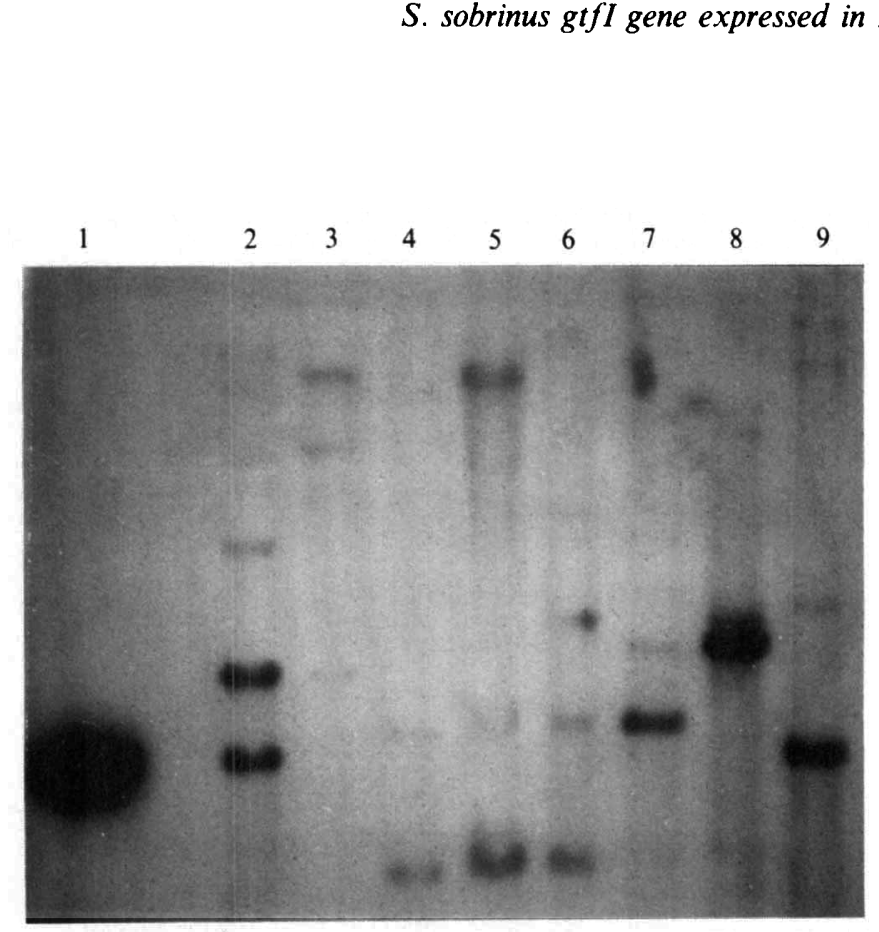

Fig. 2

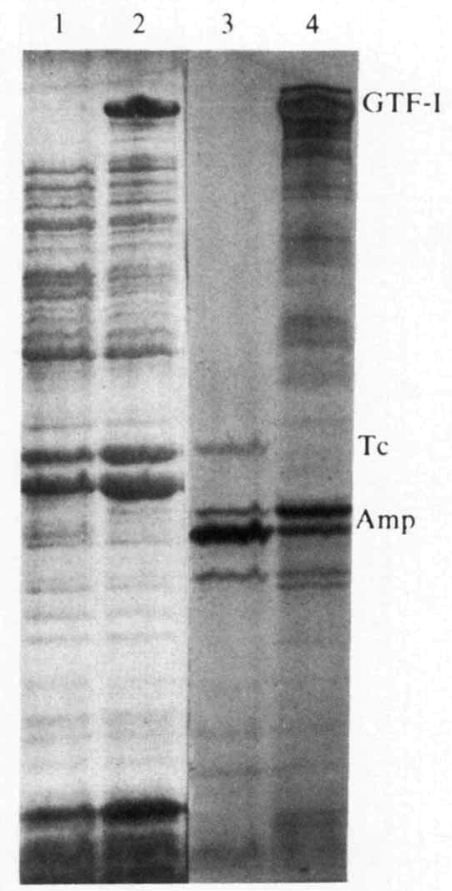

Fig. 3

Fig. 2. Southern blot hybridization of a $3.3 \mathrm{kbp} \mathrm{HpaI} \mathrm{DNA} \mathrm{fragment} \mathrm{from} \mathrm{within} \mathrm{gene} \mathrm{gtfl} \mathrm{(see} \mathrm{Fig.} \mathrm{1)}$ to: lane 1, 3.3 kbp HpaI DNA probe; lanes 2-9, HpaI-cleaved chromosomal DNA of representative strains of mutans streptococci: lane 2, $S$. cricetus strain AHT (serotype $a$ ); lane 3, $S$. rattus strain FA1 (serotype $b$ ); lane 4, $S$. mutans strain Ingbritt (serotype $c$ ); lane 5, $S$. mutans strain C40 (serotype $e$ ); lane 6, S. mutans strain 151 (serotype $f$ ); lane $7, S$. sobrinus strain B13 (serotype $d$ ); lane $8, S$. sobrinus strain K1 (serotype $g$ ); lane 9, $S$. sobrinus strain MFe28 (serotype $h$ ).

Fig. 3. Analysis of the polypeptides expressed by minicells of E. coli strain DS410 carrying plasmids pBR322 or pMLG10. The polypeptides were analysed by SDS-PAGE after incorporation of L${ }^{35}$ S $]$ methionine and stained with Coomassie brilliant blue (lanes 1 and 2) followed by autoradiography (lanes 3 and 4). Minicells harboured: lanes 1 and 3, pBR322 (control); lanes 2 and 4, pMLG10. GTF-I, $\mathrm{Tc}$ and Amp indicate migration of proteins encoded by the gtfl, tet and amp genes.

active GTF-I (Fig. 1). However, pMLG1B codes for an enzymically inactive protein of about $120 \mathrm{kDa}$ which was detected by Western blotting using antiserum raised against GTF-I (data not shown). This suggests that the promoter for initiating transcription of gene gtfI lies within the $1.55 \mathrm{kbp} \mathrm{BglII-BamHI}$ fragment of pMLGl. Moreover, some of the other recombinant pBR322 subclones studied carried the $5 \mathrm{kbp}$ HindIII insert in reverse orientation (data not shown) and expressed $g t f I$. This strongly suggests that transcription of $g t f I$ originates from the cloned DNA of $S$. sobrinus strain MFe28 and not from the vector plasmid pBR322.

\section{Occurrence of DNA sequences homologous to gtfI among strains of mutans streptococci}

An internal $3.3 \mathrm{kbp} \mathrm{HpaI}$ fragment of the gtfI sequence (Fig. 1) was selected to probe HpaIdigested chromosomal DNA from representatives of the different species of mutans streptococci. Sequences with homology with the probe were found in all the strains tested, but only $S$. sobrinus strain MFe28 (serotype $h$ ) and $S$. cricetus AHT (serotype $a$ ) carried fragments identical in size to the $3.3 \mathrm{kbp}$ probe (Fig. 2). In all strains (most obviously in $S$. cricetus strain AHT) there existed more than one chromosomal fragment with a sequence capable of hybridizing with the probe. The possibility that the detection of such multiple hybridization fragments was due to incomplete digestion of the chromosomal DNA was excluded by a series of experiments in which digestion with $\mathrm{HpaI}$ was allowed to proceed for different times. 


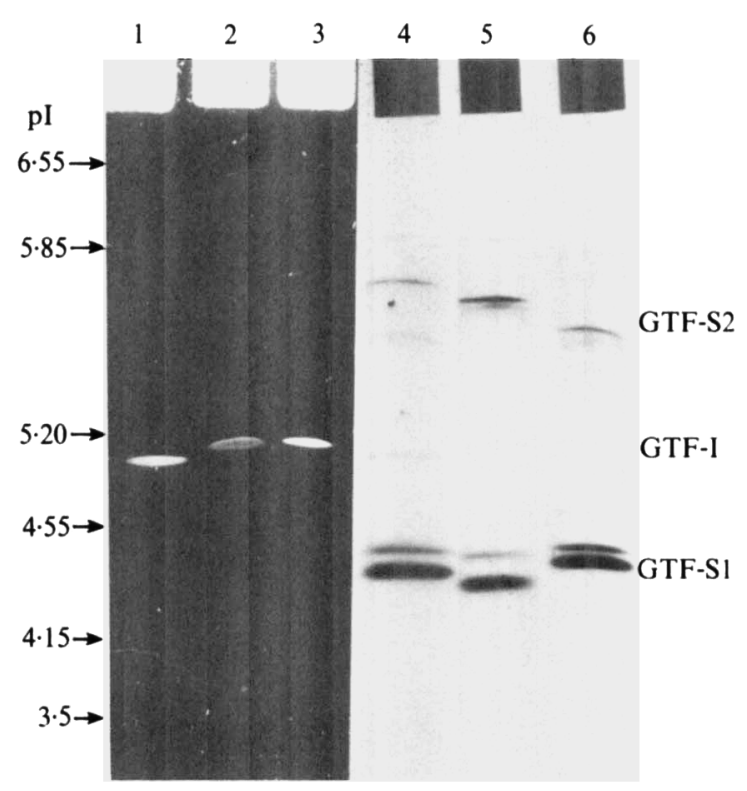

Fig. 4

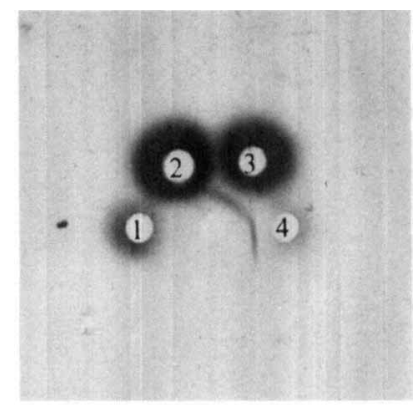

Fig. 5

Fig. 4. Isoelectric focusing patterns of GTF activities in cultures of $S$. sobrinus strains B13 (serotype $d$, lanes 1 and 4), 6715 (serotype $g$, lanes 2 and 5) and MFe28 (serotype $h$, lanes 3 and 6). Insoluble glucan could be seen by dark-ground illumination (lanes 1-3) and soluble glucans after PAS staining (lanes 46). The arrows indicate the positions of standards from the isoelectric focusing calibration kit (Pharmacia).

Fig. 5. Immunodiffusion analysis of reactions between GTF-I purified from $E$. coli strain MAF10 (centre well) and antisera raised against GTF-S1 (well 1), GTF-S2 (well 2) and GTF-I (well 3) purified from $S$. sobrinus strain 6715 . Well 4 contained homologous antiserum raised against GTF-I purified from $E$. coli strain MAF10.

\section{Minicell analysis of the polypeptides encoded by pMLG10}

The polypeptides encoded by plasmid pMLG10 were compared with those specified by plasmid pBR322 in a minicell system using $E$. coli strain DS410 as the host. The polypeptides were analysed by SDS-PAGE after incorporation of L- $\left[{ }^{35} S\right]$ methionine. Comparison of the Coomassie brilliant blue stained pattern of proteins in $E$. coli strain DS410 bearing either pBR322 or pMLG10 indicated a high level of expression of $g t f I$ (Fig. 3). The major band of GTF-I had a molecular mass of approximately $160 \mathrm{kDa}$ but multiple bands of lower molecular mass were also detectable in the autoradiograph (Fig. 3). It would appear that these are all degradation products of GTF-I, since antiserum to GTF-I reacted with bands of a multiplicity of sizes in Western blot experiments. In addition, several bands just below the one of $160 \mathrm{kDa}$ had GTF activity on SDS-PAGE gels (not shown).

\section{Isoelectric focusing of glucosyltransferases}

Since the characterization of GTFs of $S$. sobrinus serotype $h$ by isoelectric focusing has not previously been reported, culture supernatants of $S$. sobrinus strains B13 (serotype $d$ ), 6715 (serotype $g$ ) and MFe28 (serotype $h$ ) were subjected to isoelectric focusing on thin layers of polyacrylamide gel (Fig. 4). Although for each strain only a single band of GTF-I activity was visible in unstained gels, the two zones of GTF-S activity always gave a series of minor bands close to the major ones, visible after PAS staining, as previously reported (Tsumori et al., 1983). The pI of major GTF bands resolved by isoelectric focusing varied by up to $0.2 \mathrm{pH}$ units from experiment to experiment. The results summarized in Table 1 are the means of at least three determinations for each strain and show that the three strains of $S$. sobrinus (serotypes $d, g$ and $h$ ) 
Table 1. Isoelectric points of glucosyltransferases

Isoelectric points were determined by isoelectric focusing on horizontal polyacrylamide slab gels, followed by incubation in sucrose and PAS staining. Each value is the mean of at least three separate determinations.

\begin{tabular}{llccc}
\multirow{2}{*}{ Species } & $\begin{array}{c}\text { Strain } \\
\text { (serotype) }\end{array}$ & $\overbrace{\text { GTF-S1 }}$ & GTF-S2 & GTF-I \\
S. sobrinus & B13 $($ d $)$ & $4 \cdot 0$ & $5 \cdot 6$ & $4 \cdot 8$ \\
& $6715(g)$ & 3.9 & $5 \cdot 6$ & $5 \cdot 0$ \\
E. coli & MFe28 $(h)$ & $4 \cdot 2$ & $5 \cdot 6$ & $4 \cdot 9$ \\
MAF10 & - & - & 4.9
\end{tabular}

* E. coli strain DHl carrying recombinant plasmid pMLGl0.

gave closely similar results. Recombinant $E$. coli strain MAF 10 contained no detectable GTF-S activity, but had a GTF-I band with a pI the same as that of the GTF-I found in $S$. sobrinus strain $\mathrm{MFe} 28$ and close to those of the other $S$. sobrinus strains (Table 1).

\section{Immunological relationship of GTF}

We previously reported that the enzyme encoded by $g t f I$ reacted with antiserum to GTF of $S$. sobrinus strain K1 (serotype $g$ ) (Gilpin et al., 1985). Immunodiffusion analysis was used to investigate the reaction of the enzyme with antisera raised against GTF-S1, GTF-S2 and GTF-I from another $S$. sobrinus strain, 6715 (serotype $g$ ), purified by procedures described elsewhere (Shimamura et al., 1985; Mukasa, 1986). No reaction was seen between GTF-I purified from $E$. coli strain MAF10 and antiserum to GTF-S1 or GTF-S2, but a strong precipitin line was observed between the antigen and antiserum raised against GTF-I. A line of identity was formed by the antisera raised against GTF-I purified from $E$. coli strain MAF10 and against GTF-I from $S$. sobrinus strain 6715 (Fig. 5).

By immunodiffusion, antigens related to the cloned GTF-I could be detected in culture supernatants only of mutans serotypes $a, d, g$ and $h$ (i.e. $S$. cricetus and $S$. sobrinus), but the more sensitive Western blotting technique revealed cross-reactive antigens in all eight serotypes $a-h$ (data not shown). In every case multiple bands were detected by Western blotting, but it is not known whether this was due to the degradation of the highest molecular mass form of GTF-I or to antigenic cross-reactivity with other GTFs.

\section{Analysis of glucan synthesized by E. coli strain MAF 10}

The insoluble glucan produced by incubation of crude extracts of $E$. coli strain MAF10 with sucrose was converted into partially methylated alditol acetates. The derivatives of 2,3,4,6-tetra2,4,6-tri-, 2,3,4,-tri- and 2,4-di-O-methyl D-glucitol were detected at $0 \cdot 4,88 \cdot 4,2 \cdot 4$ and $0.5 \mathrm{~mol} \%$ respectively, with $8.2 \%$ unknown derivatives. The glucan thus consisted of $88 \% 1,3,-\alpha-\mathrm{D}-$ glucosyl residues with $2.4 \% 1,6-\alpha$-glucosyl residues. NMR analysis of the glucan was in agreement with this composition as, based on peak areas (Fig. 6), the glucan was calculated to consist of $94 \cdot 4 \% 1,3-\alpha$-D-glucan and $5 \cdot 6 \%$ unknown components. The nature of the unidentified linkages is not, at present, clear.

\section{DISCUSSION}

We have previously reported that the GTFs of $S$. sobrinus serotype $h$ strains closely resemble those of strains of serotypes $d$ and $g$ (Beighton et al., 1981). Those findings were extended by the present work which showed that strain MFe28 (serotype $h$ ) contained three GTFs resolvable by isoelectric focusing and that these had isoelectric points close to those of enzymes GTF-S1, GTF-S2 and GTF-I previously described for serotype $d$ and $g$ strains (Shimamura et al., 1983; Tsumori et al., 1983; Mukasa, 1986). Despite these similarities between GTFs however, serotype $h$ strains differ from those of serotypes $d$ and $g$ in a number of other respects, and 


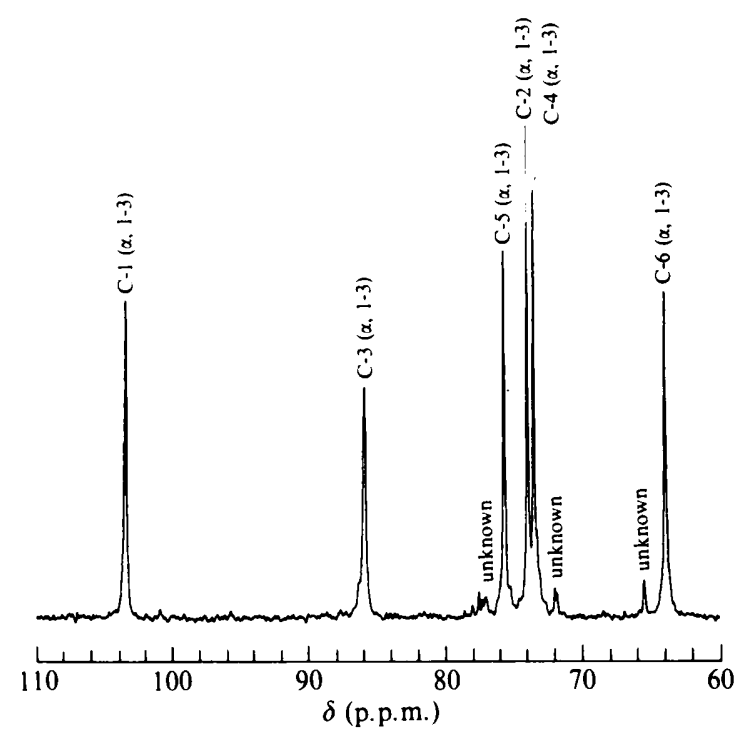

Fig. $6 .{ }^{13} \mathrm{C}$ NMR spectrum of water-insoluble glucan produced by an extract of recombinant $E$. coli strain MAF 10, which carries $g t f I$ on plasmid pMLG10. Based on peak areas, the glucan was calculated to consist of $94.4 \% 1,3-\alpha$-D-glucan and $5.6 \%$ unknown components.

DNA-DNA hybridization studies indicate that serotype $h$ should constitute a distinct subspecies of S. sobrinus (R. A. Whiley, J. Hardie, R. R. B. Russell and D. Beighton, unpublished data). It should also be noted that the strains of serotypes $d$ and $g$ used in this study differed from each other and from strain MFe28 (serotype $h$ ) in the Southern blot experiment with the gtfI probe (Fig. 2).

The preliminary characterization of the GTF synthesized in $E$. coli infected with recombinant bacteriophage $\lambda$ carrying the $g t f I$ gene showed that its molecular mass matched that of an enzyme in S. sobrinus strain MFe28 (Morrissey et al., 1985). The GTF expressed in E. coli also occurred in a form with a $\mathrm{pI}$ the same as that of the enzyme in $S$. sobrinus strain MFe28 (Table 1), but studies of both molecular mass and pI were complicated by the degradation of GTF during storage, regardless of the species by which it was synthesized. It is possible to reduce this degradation in streptococcal species by early harvesting of cultures, maintenance of low temperatures and addition of the protease inhibitor phenylmethylsulphonyl fluoride (Mukasa, 1986; Russell et al., 1986), but we have not yet found a way of preventing degradation in E. coli. As a result, we are as yet unable to arrive at a precise molecular mass of GTF-I or indeed even to be fully confident that we have cloned the entire gene. This issue will, however, be resolved by DNA-sequencing studies currently in progress.

Analysis of the glucan produced from sucrose by the cloned GTF-I showed it to consist almost entirely of 1,3- $\alpha$-D-glucosyl residues. The enzyme is thus confirmed to be comparable to that purified from strain 6715-15 by Fukui et al. (1982) and referred to by them as mutansynthetase (EC 2.4.1 . ?). The pI of 4.9 is close to that of GTF-I reported by others for strains of serotypes $d$ and $g$ (Tsumori et al., 1983; Furuta et al., 1985; Namiki et al., 1985; McCabe 1985). There was also a close immunological relationship between GTF-I of serotypes $d, g$ and $h$, detectable by immunodiffusion. The use of the more sensitive Western blotting revealed a wider conservation of antigenic determinants in all eight mutans serotypes $a-h$. The data from DNA hybridization experiments with a $g t f I$ gene probe were fully consistent with this result since sequences homologous with an internal fragment of $g t f I$ were found in chromosomal DNA from representatives of all serotypes. In some strains, there was also evidence for the existence of more than one sequence with homology, which suggests that multiple copies of gtfI genes are present or that there is some homology between the gene for GTF-I and genes for other GTFs. 
The $g t f I$ gene probe will be of value for the screening of recombinant gene banks constructed from other mutans streptococci for such $g t f$ genes. This may be particularly useful for studies of $S$. mutans serotypes $c, e$ and $f$, which are the most common isolates from humans but with which we have so far been unsuccessful in attempts to clone $g t f I$. There is, however, the possibility that the sequences of DNA which hybridize with the gtfI gene probe do not code for a GTF, but form part of some other gene with partial homology, for example a determinant coding for glucanbinding properties.

The restriction map of $g t f I$ of $S$. sobrinus strain MFe28 will be of value for comparison with cloned genes for other GTFs. It bears no resemblance to that of a $g t f Q$ gene cloned from $S$. mutans strain GS-5 (serotype $c$ ) studied by Kuramitsu \& Aoki (1986). Morever, our own experiments (unpublished data) indicate that the $g t f l$ gene is quite distinct from the $g t f S$ gene we have cloned from $S$. sobrinus MFe28 (serotype $h$ ) (Gilpin et al., 1985). The nature of the product, independence of primer and pI of 5.5 (R. R. B. Russell, unpublished) show that the enzyme encoded by the latter gene corresponds to that referred to as GTF-S2 by Mukasa (1986) and as GTF-S4 by McCabe (1985). The isoelectric focusing results in this paper indicate that there also exists a third, primer-dependent GTF-Sl enzyme in MFe28 and we intend to rescreen our recombinant gene bank for this.

The availability of recombinant $E$. coli strains carrying the genes for individual GTFs will greatly facilitate purification of the enzymes for biochemical studies and also make it possible to investigate the genetic relatedness and evolution of the multiple forms of GTF found amongst the streptococci and related genera.

The authors are grateful to Atsunari Shimamura for assistance in determination, by GLC and NMR, of the structure of the glucan synthesized by GTF-I. Financial support was provided by the DHSS and MRC.

\section{REFERENCES}

Asem, G. A., Kenney, A. C. \& Cole, J. A. (1986). Origin and function of the multiple extracellular glycosyltransferase species from cultures of a serotype $c$ strain of Streptococcus mutans. Archives of Biochemistry and Biophysics 244, 607-618.

Beighton, D., Russell, R. R. B. \& Hayday, H. (1981). The isolation and characterization of Streptococcus mutans serotype $h$ from dental plaque of monkeys (Macaca fascicularis). Journal of General Microbiology 124, 271-279.

Ciardi, J. E., Hageage, G. J. \& Wittenberger, C. L. (1976). Multicomponent nature of the glucosyltransferase system of Streptococcus mutans. Journal of Dental Research 55C, 87-96.

Ciardi, J. E., Beaman, A. J. \& Wittenberger, C. L. (1977). Purification, resolution, and interaction of the glucosyltransferases of Streptococcus mutans 6715. Infection and Immunity 18, 237-246.

Cohen, S. N., Chang, A. C. Y. \& Hsu, L. (1973). Nonchromosomal antibiotic resistance in bacteria: genetic transformation of Escherichia coli by R-factor DNA. Proceedings of the National Academy of Sciences of the United States of America 69, 21102114.

Colson, P., Jennings, H. H. \& Smith, I. C. P. (1974). Composition, sequence and conformation of polymers and oligomers of glucose as revealed by carbon13 nuclear magnetic resonance. Journal of the American Chemical Society 96, 8081-8087.

CoYkendall, A. L. (1983). Streptococcus sobrinus nom. rev. and Streptococcus ferus nom. rev.: habitat of these and other mutans streptococci. International Journal of Systematic Bacteriology 33, 883-885.
Coykendall, A. L. \& Gustafson, K. B. (1986). Taxonomy of Streptococcus mutans. In Molecular Microbiology and Immunobiology of Streptococcus mutans, pp. 21-28. Edited by S. Hamada, S. M. Michalek, H. Kiyono, L. Menaker \& J. R. McGhee. Amsterdam: Elsevier.

DAvis, R. W., Botstein, D. \& Roth, J. R. (1980). Advanced Bacterial Genetics: a Manual for Genetic Engineering, pp. 116, 117. Cold Spring Harbor, NY: Cold Spring Harbor Laboratory.

Dougan, G. \& KehoE, M. (1984). The minicell system as a method for studying expression from plasmid DNA. Methods in Microbiology 17, 233-258.

Feinberg, A. P. \& Vogelstein, B. (1983). A technique for radiolabelling DNA restriction endonuclease fragments to high specific activity. Analytical Biochemistry 132, 6-13.

Figures, W. R. \& Edwards, J. R. (1981). DGlucosyltransferase of Streptococcus mutans: isolation of two forms of the enzyme that bind to insoluble dextran. Carbohydrate Research 88, 107117.

Fukui, K., Moriyama, T., Miyake, Y., Mizutani, K. \& TANAKA, O. (1982). Purification and properties of glucosyltransferase responsible for water-insoluble glucan synthesis from Streptococcus mutans. Infection and Immunity 37, 1-9.

Fukushima, K., Motoda, R., Takada, K. \& Ikeda, T. (1981). Resolution of Streptococcus mutans glucosyltransferases into two components essential to waterinsoluble glucan synthesis. FEBS Letters 128, 213216. 
Furuta, T., Koga, T., Nisizawa, T., Okahashi, N. \& Hamada, S. (1985). Purification and characterization of glucosyltransferases from Streptococcus mutans 6715. Journal of General Microbiology 131, 285293.

Germaine, G. R., Harlander, S. K., Leung, W.-L. S. \& Schachtele, C. F. (1977). Streptococcus mutans dextransucrase: functioning of primer dextran and endogenous dextran in water-soluble and waterinsoluble glucan synthesis. Infection and Immunity 16, 637-648.

Gilpin, M. L., Russell, R. R. B. \& MorRissey, P. (1985). Cloning and expression of two Streptococcus mutans glucosyltransferases in Escherichia coli K-12. Infection and Immunity 49, 414-416.

GugGeNHEIM, B. \& NEWBRUN, E. (1969). Extracellular glucosyltransferase activity of an HS strain of Streptococcus mutans. Helvetia odontologica acta 16, 637-648.

Hamada, S. \& Slade, H. D. (1980). Biology, immunology and cariogenicity of Streptococcus mutans. Microbiological Reviews 44, 331-384.

Hare, M. D., Svensson, S. \& Walker, G. J. (1978). Characterization of the extracellular, water-insoluble $\alpha$-D-glucans of oral streptococci by methylation analysis, and by enzymic synthesis and degradation. Carbohydrate Research 66, 245-264.

Koga, T., Sato, S., Yakushiji, T. \& Inoue, M. (1983). Separation of insoluble and soluble glucan-synthesizing glucosyltransferases of Streptococcus mutans OMZ176 (serotype d). FEMS Microbiology Letters 16, 127-130.

KURAMitsu, H. K. \& AOKI, H. (1986). Isolation and manipulation of Streptococcus mutans genes. In Molecular Microbiology and Immunobiology of Streptococcus mutans, pp. 199-204. Edited by S. Hamada, S. M. Michalek, H. Kiyono, L. Menaker \& J. R. McGhee. Amsterdam: Elsevier.

Loenen, W. A. M. \& Brammar, W. J. (1980). A bacteriophage lambda vector for cloning large DNA fragments made with several restriction enzymes. Gene 20, 249-359.

Maniatis, T., Fritsch, E. F. \& Sambrook, J. (1982). Molecular Cloning : a Laboratory Manual, pp. 80-82, 85, 93, 382-389. Cold Spring Harbor, NY: Cold Spring Harbor Laboratory.

MCCABE, M. M. (1985). Purification and characterization of a primer-independent glucosyltransferase from Streptococcus mutans 6715-13 mutant 27. Infection and Immunity 50, 771-777.

MCCABE, M. M. \& Smith, E. E. (1977). Specific method for the purification of Streptococcus mutans dextransucrase. Infection and Immunity 16, 760-765.

McDonnell, M. W., Simon, M. N. \& StUdieR, F. W. (1977). Analysis of restriction fragments of T7 DNA and determination of molecular weights by electrophoresis in neutral and alkaline gels. Jourral of Molecular Biology 110, 119-146.

Monsen, T. J., Holm, S. E. \& Burman, L. G. (1983). A general method for cell lysis and preparation of deoxyribonucleic acid from streptococci. FEMS Microbiology Letters 16, 19-24.

Morrissey, P., Dougan, G., Russell, R. R. B. \& GILPIN, M. (1985). Cloning of Streptococcus mutans antigens in Escherichia coli $\mathrm{K} 12$ as an aid to the development of a dental caries vaccine. In Vaccines 85, pp. 117-120. Edited by R. A. Lerner, R. A. Chanock \& F. Brown. Cold Spring Harbor, NY: Cold Spring Harbor Laboratory.

MUKasA, H. (1986). Properties of Streptococcus mutans glucosyltransferases. In Molecular Microbiology and Immunobiology of Streptococcus mutans, pp. 121-132. Edited by S. Hamada, S. M. Michalek, H. Kiyono, L. Menaker \& J. R. McGhee. Amsterdam: Elsevier.

Mukasa, H. \& Slade, H. D. (1973). Mechanism of adherence of Streptococcus mutans to smooth surfaces. 1. Role of insoluble dextran-levan synthetase enzymes and cell wall polysaccharide antigen in plaque formation. Infection and Immunity 8, 555-562.

Namiki, Y., Kantake, I., IKedA, T. \& FukUShIMA, K. (1985). Separation of three kinds of glucosyltransferases from Streptococcus mutans strain B13. IRCS Medical Science 13, 501-502.

ONo, K., INOUE, M. \& SMITH, E. E. (1984). Specific and non-specific affinities of the extracellular glucosyltransferase complex of Streptococcus mutans 6715. Carbohydrate Research 134, 245-264.

RoByt, J. F. \& MARTIN, P. J. (1983). Mechanism of synthesis of D-glucans by D-glucosyltransferases from Streptococcus mutans 6715. Carbohydrate Research 113, 301-315.

RUSSELL, R. R. B. (1979). Glucosyltransferases of Streptococcus mutans Ștrain Ingbritt. Microbios 23, $135-146$.

Russell, R. R. B., Coleman, D. \& Dougan, G. (1985). Expression of a gene for glucan-binding protein from Streptococcus mutans in Escherichia coli. Journal of General Microbiology 131, 295-299.

Russell, R. R. B., Abdulla, E., Gilpin, M. L. \& SMITH, K. (1986). Characterization of Streptococcus mutans surface antigens. In Molecular Microbiology and Immunobiology of Streptococcus mutans. pp. 6170. Edited by S. Hamada, S. M. Michalek, H. Kiyono, L. Menaker \& J. R. McGhee. Amsterdam: Elsevier.

Shimamura, A., Tsumori, H. \& Mukasa, H. (1982). Purification and properties of Streptococcus mutans extracellular glucosyltransferase. Biochimica et biophysica acta 719, 81-89.

Shimamura, A., Tsumori, H. \& Mukasa, H. (1983). Three kinds of extracellular glucosyltransferases from Streptococcus mutans 6715. (serotype g). FEBS Letters 157, 79-83.

SouTHERN, E. (1975). Detection of specific sequences among DNA fragments separated by gel electrophoresis. Journal of Molecular Biology 98, 503-517.

TeRleCKyJ, B., Willett, P. N. \& Shockman, G. D. (1975). Growth of several cariogenic strains of oral streptococci in a chemically defined medium. Infection and Immunity 11, 649-655.

Tsumori, H. Shimamura, A. \& Mukasa, H. (1983). Comparative study of Streptococcus mutans extracellular glycosyltransferases by isoelectric focusing. Journal of General Microbiology 129, 3261-3269.

Yokogawa, K., Kawata, S., Takemura, T. \& Yoshimura, Y. (1975). Purification and properties of lytic enzymes from Streptomyces globisporus 1829. Agricultural and Biological Chemistry 39, 1533-1543. 